\title{
Kentsel yerleşim alanlarında çevresel gürültünün belirlenmesi: Bursa Dikkaldırım Mahallesi örneği
}

\author{
Determination of environmental noise in urban settlements: Bursa Dikkaldırım \\ Neighborhood example
}

\author{
Melike YALILI KILIÇ ${ }^{* 1, a}$, İlker KILIÇ ${ }^{2, b}$, Sümeyye ADALI ${ }^{1, \mathrm{c}}$ \\ ${ }^{1}$ Bursa Uludağ Üniversitesi, Mühendislik Fakültesi, Çevre Mühendisliği Bölümü, 16059, Bursa \\ ${ }^{2}$ Bursa Uludağ Üniversitesi, Ziraat Fakültesi, Biyosistem Mühendisliği Bölümü, 16059, Bursa
}

• Geliş tarihi / Received: 22.02.2021 • • Düzeltilerek geliş tarihi / Received in revised form: 03.05.2021 • Kabul tarihi / Accepted: 08.05 .2021

Öz

Günümüzde kentsel alanlarda gürülttü kirliliği önemli bir çevre sorunu haline gelmiştir. Özellikle trafik yoğunluğunun yaşandığı bölgeler gürültü açısından büyük risk altındadır. Bu çalışmada, Bursa ili, Osmangazi ilçesinde kentin en büyük parkı, stadyum, konut yapıları, eğitim, sağlık ve güvenlik kurumlarına yakın olan bir bölgede yer alan Dikkaldırım Mahallesi'nde çevresel gürültü seviyesi belirlenmeye çalışılmıştır. Mahalle çevresinde gürültü açısından hassas noktalar belirlenerek, bu noktalarda mart-nisan-mayıs aylarında hafta içi perşembe ve cuma, hafta sonu cumartesi, pazar günleri sabah, öğle ve akşam saatlerinde ölçümler yapılmıştır. Elde edilen sonuçlar istatistiksel olarak incelenmiş olup, Çevresel Gürültünün Değerlendirilmesi ve Yönetimi Yönetmeliği (ÇGDYY)'ne göre klyaslanarak bölge özelinde yönetmelikle belirlenen sınır değerlerin sağlanıp sağlanmadığı belirlenmiştir. Çalışma sonucunda, gürültü kirliliği seviyesinin 60-97 dBA aralığında oluştuğu ve mevcut yönetmelik (ÇGDYY) sınırlarının üzerinde olması nedeniyle çevre ve insan sağlığını tehdit eder düzeye ulaştığı belirlenmiştir. Gürültü kirliliği azaltımı için uygulanabilecek çeşitli öneriler sunulmuştur.

Anahtar kelimeler: Bursa, Gürültü, Kentsel gürültü, Trafik

\begin{abstract}
Today, noise pollution has become an important environmental problem in urban areas. Especially regions with high traffic are at great risk in terms of noise. In this study, the environmental noise level was tried to be determined in Dikkaldırm Neighborhood, which is located in an area close to the biggest park, stadium, residential buildings, education, health and safety institutions of the city in Osmangazi district of Bursa city. Sensitive points in terms of noise were determined around the neighborhood and measurements were made at these points in the morning, afternoon and evening hours on weekdays, Thursdays and Fridays, weekends and Sundays in March-April-May. The results obtained were statistically analyzed and compared according to the Regulation on the Assessment and Management of Environmental Noise (RAMEN), it was determined whether the limit values determined by the regulation were met or not. As a result of the study, it was determined that the level of noise pollution occurred in the range of 60-97dBA and reached a level that threatens the environment and human health because it is above the current regulation (RAMEN) limits. Various suggestions for noise pollution reduction are presented.
\end{abstract}

Keywords: Bursa, Noise, Urban noise, Traffic

\footnotetext{
${ }^{*}$ a Melike YALILI KILIÇ; myalili@uludag.edu.tr; Tel: (0224) 29421 17; orcid.org/0000-0001-7050-6742

${ }^{\mathrm{b}}$ orcid.org/0000-0003-0087-6718 $\quad{ }^{\mathrm{c}}$ orcid.org/0000-0002-5077-7358
} 


\section{Giriş}

Günümüzde kentleşme ve teknolojinin gelişmesiyle beraber daha yoğun şekilde hissedilmeye başlayan gürültü kirliliği, özellikle kent merkezlerinde oluşturduğu rahatsızlıktan dolayı büyük bir çevre problemi haline gelmeye başlamıştır (Morova vd., 2010). Dünya Sağlık Örgütü (DSÖ) tarafından gürültünün sağlık problemlerine yol açan en önemli ikinci çevre problemi olduğu bildirilmektedir (WHO, 2011; Savaş, 2019).

Yüksek gürültü maruziyeti, dünya genelinde işitme kayıplarının en yaygın nedeni olarak gösterilmektedir (Tekin, 2020). ABD, Şili, Meksika, Kanada, Avustralya gibi ülkelere ait gürültü yönetmelikleri incelendiğinde, gürültünün zararlı olmaya başladığı sınırın 8 saatlik bir süre için 85-90 dBA aralığında oluştuğu belirtilmektedir (Morova vd., 2010; Dadaş ve Demirel, 2019).

Gürültü kaynakları, kaynak ve alıcıların konum ve yayılma yollarına bağlı olarak yapı dışı ve yapı içi çevre gürültüleri olmak üzere ikiye ayrılmaktadır (Taşkaya ve Sesli, 2019). Yapı içi gürültü kaynakları arasında konuşma sesleri, ev araçları gürültüsü, müzik sesleri, büro gürültüleri, garaj gürültüleri, makine ve donanım gürültüleri (asansör, tesisat v.b.), işyeri gürültüleri; yapı dış1 gürültü kaynakları arasında ise trafik gürültüleri (karayolu, denizyolu, demiryolu, uçak ve havaalanı gürültüleri), endüstri gürültüleri, yapım (şantiye) gürültüleri, insan faaliyetlerinden kaynaklı gürültüler, eğlence ve ticari amaçlı faaliyetler sonucu oluşan gürültüler yer almaktadır (T.C. Çevre ve Orman Bakanlığı, 2011). Ülkemizde yap1 içi gürültüden kaynaklı olarak turizm merkezlerine tatil ve dinlenme amaçlı gelen insanların gürültü kirliliğinden zarar görmesinin engellenmesi amacıyla örnek seçilen bir otelde gürültü seviyelerinin tespit edilerek gürültü haritası hazırlanmış olup, gerekli önlemlerin yurt çapında alınması için veri oluşturması yoluna gidilmiştir (Özdemir vd., 2011). Bunun yanısıra ülkemizde trafik kaynaklı gürültünün okul, hastahane, otel vb. hassas yapılardaki olumsuz etkilerini azaltmak için atık malzemelerden gürültü yalıtımı için panel üretim çalışmaları da yapılmıştır (İlgün vd., 2010).

Kentsel alanlarda meydana gelen gürültünün $\% 80$ 'i trafikten kaynaklanmaktadır. Bu nedenle trafik gürültüsü kentlerde insan refahını etkileyen en yaygın ve en büyük gürültü kaynağı olarak görülmektedir (Aktürk vd., 2003; Delikanlı vd., 2014). Trafik gürültüleri arasında en büyük çevresel etki karayolu gürültülerine aittir. Karayolu gürültüsü, yerleşim yerlerinin tamamında yaygın ve sürekli olması dolayısıyla rahatsız ediciliği yüksek olan bir gürültü kaynăğıdır. Karayollarındaki araç sayıları ve ağılıkları, araç hızları, engebeli ve bozulmuş yollar, dönemeç ve kavşaklar gibi parametreler karayollarında oluşan gürültü seviyesi üzerine etki etmektedir (Paşaoğlu, 2013).

Kentsel bölgelerde oluşan gürültü kirliliğini belirlemek amacıyla yapılan çalışmalar incelendiğinde, literatürde pek çok çalışmanın yer aldığı görülmektedir. Özyonar ve Peker (2008) tarafından Sivas şehir merkezinde çevresel gürültü düzeyini belirlemek amaciyla, trafik ve nüfus yoğunluğunun yüksek olduğu cadde, sokak ve kavşaklarda gürültü ölçümleri gerçekleştirilmiştir. Avanos ilçe merkezinde 24 noktada yapılan çalışmada eşdeğer gürültü ölçüm seviyelerinin gündüz 79-85 dBA aralığında olduğu ve ilçe girişçıkış karayollarındaki maksimum gürültü seviyesinin Lmax 109 dBA, minimum Lmin 82 dBA olduğu belirlenmiştir (Kalıpc1, 2017). Gaziantep'te nüfus yoğunluğu yüksek olan bölgelerde karayolu trafiğinden kaynaklanan stratejik gürültü haritaları oluşturularak, yüksek seviyede gürültü maruziyeti yaşayan bölgelerdeki nüfus oranları tespit edilmeye çalışılmışıtır (Tercan ve Yaman, 2021). İstanbul ili Beykoz ilçesi Kavacık mevkiindeki TEM Otoyolu üzerinde gürültü ölçümleri yapılarak bölgenin gürültü haritası oluşturulmuş ve gürültünün yerleşim alanına etkisini azaltmak için çözüm önerileri sunulmuştur (Savaş, 2019). Torun ve Bingül (2014), Erzurum'da demiryollarında gürültü ölçümleriyle maksimum, minumum ve eşdeğer gürültü seviye parametrelerini hesaplayarak demiryolu çevresinde oluşan gürültü seviyesini belirlemişlerdir. Konya ili Sarayönü ilçesinde 44 noktada yapılan çalışmada gürülttü ölçüm seviyelerinin sabah 45-103 dBA, öğlen 44-90 dBA ve akşam 39-82 dBA aralığında olduğu belirlenmiştir (Öden ve Bilgin, 2019). Bu çalışmanın haricinde Konya'da trafikten kaynaklı gürültü için yapılmış farklı araştırmalar da mevcuttur (Kalıpc1 ve Aslan, 2007; Özdemir vd., 2012). Delikanlı vd., (2014), Bartın ilinde yerleşim alanları yakınlarında araç trafiğinin yoğun olduğu noktalarda gürültü ölçümleri gerçekleştirerek trafik kaynaklı çevresel gürültüyü belirlemişlerdir.

$\mathrm{Bu}$ çalışmada, Bursa ilinin Osmangazi ilçesi Dikkaldırım Mahallesi'nde oluşan çevresel gürültü seviyesi belirlenmiştir. Bölgede gözlemler gerçekleştirilerek gürültünün yoğun olarak meydana geldiği noktalarda hafta içi perşembe ve 
cuma, hafta sonu cumartesi ve pazar günleri, sabah, öğle ve akşam vakitlerinde ölçümler yapılarak gürültü seviyesi tespit edilmiş, oluşan gürültüye karşı alınabilecek önlemler sıralanmıştır.

\section{Materyal ve metot}

Gürültü kirliliği kentlerdeki nüfus artışına bağl1 olarak her alanda insanları etkilemektedir. $\mathrm{Bu}$ alanlardan birisi de yerleşim yerleridir. Bu çalışma Bursa ilinin Osmangazi ilçesinde bulunan Dikkaldırım Mahallesi'ndeki trafikten kaynaklı gürültü kirliliği düzeyinin belirlenmesi amacıyla gerçekleştirilmiştir. Dikkaldırım Mahallesi Bursa'nın en eski mahallelerinden biri olup, şehrin merkezi bir noktasında yer almaktadır
(Kaplanoğlu, 2021). Mahallenin bulunduğu bölgede $510000 \mathrm{~m}^{2}$ lik alanıyla kentin en büyük park1, stadyum, konut yapıları, eğitim, sağlık ve güvenlik kurumları bulunmaktadır. Yoğun olarak göç alan bölge, Bursa trafiğinin önemli kilit noktaları arasında yer almaktadır. Çevresel gürültü bölge için önemli bir kent sorunu haline gelmiştir.

Çalışmada öncelikle Dikkaldırım Mahallesi’nin haritası çıkarılmış ve gürültü açısından hassas noktalar belirlenmiştir. Belirlenen bu noktalarda mart-nisan-mayıs aylarında hafta içi perşembe ve cuma, hafta sonu cumartesi, pazar günleri sabah, öğle ve akşam saatlerinde ölçümler yapılmıştır. Ölçüm noktaları harita üzerinde gösterilmiştir (Şekil 1).

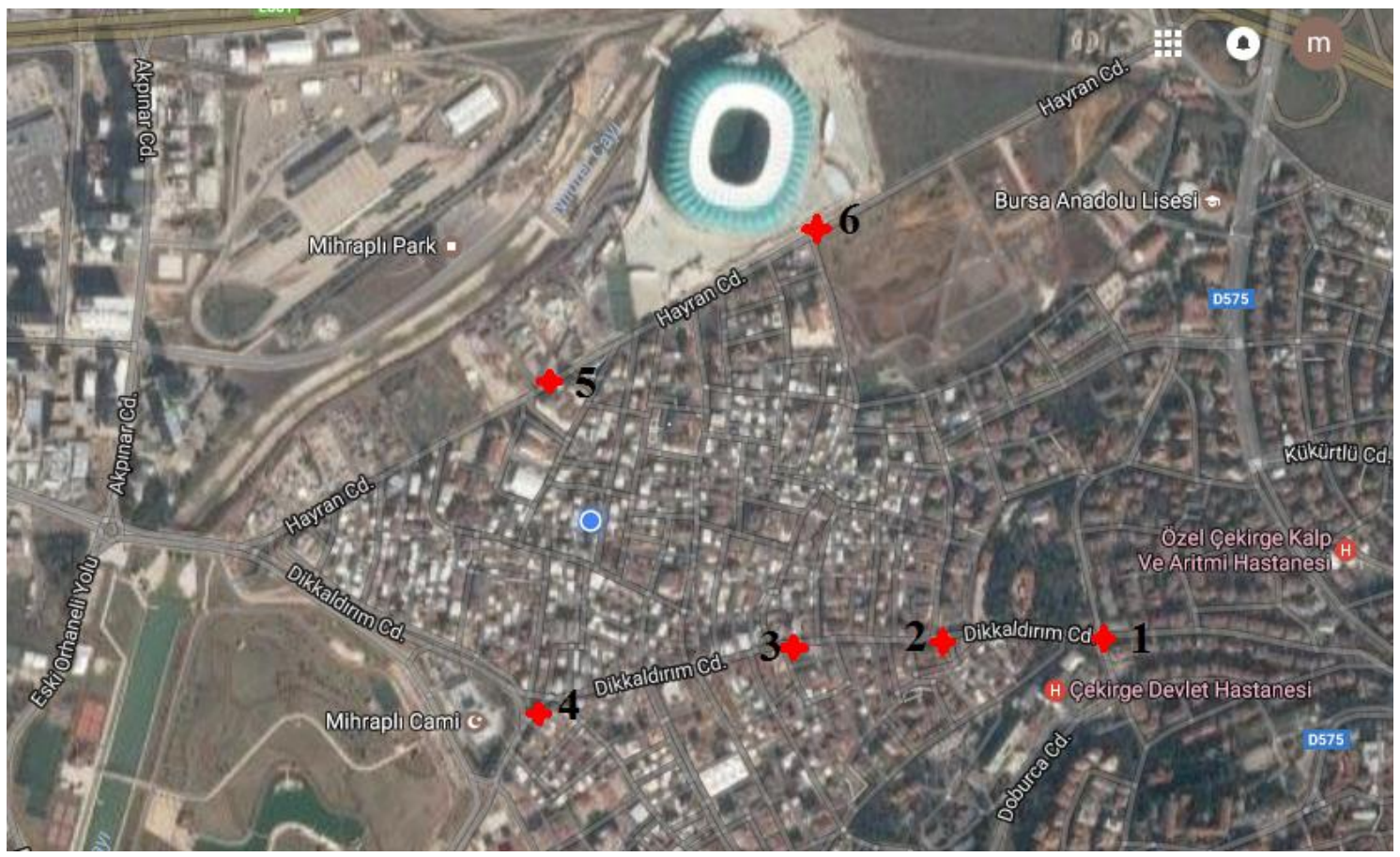

Şekil 1. Ölçüm noktalarına ait uydu görüntüsü (26.01.2021)

Ölçümler, gürültünün yoğun olduğu saatler olan mesai başlangıç-bitiş saatleri düşünülerek seçilmiş olup, sabah 08.00-09.00, öğle 12.00-13.00 ve akşam 17.00-18.00 saatlerinde 3'er dakikalık periyotlar halinde yapılmıştır. Havanın yağışsız, rüzgarın sakin ve hafif olduğu günlerde ölçümler gerçekleştirilmiştir. Ölçümlerin iyi hava koşullarında yapılması nedeniyle meteorolojik verilerin ölçümler üzerinde önemli bir etkisinin olmadığı düşünüldüğünden kayıt altına alınmamıştır. Çalışma süresince ölçüm materyali olarak EXTECH 407738 (Sound Level Meter) kullanılmıştır (Şekil 2). Ölçüm materyali, Tip 2 standartlarını (ANSI S1.4-1983, IEC 60651, EN 60651) karşılamakta olup, yüksek hassasiyete sahiptir. $26 \mathrm{~dB}$ ile $130 \mathrm{~dB}$ gibi geniş bir ölçüm aralığına sahip olup, gürültü ölçümü gerçekleştirilecek çeşitli ortamlar için ideal bir araç olma özelliğindedir. Birer AC ve DC analog çıkışa sahip olan alet, IEC standardı 60942 1997-11'i karşılamaktadır (Anonim, 2021).

Ölçümler eşdeğer gürültü düzeyi (Leq) cinsinden, A ağırlıklı ses düzeyi (dBA) birimindendir. Ağaç, duvar, bina vb. gibi yüzeylerin en az $1.5 \mathrm{~m}$ uzağında gürültü ölçümü yapılmış olup, ölçüm esnasında ani rüzgâr, yağış, yüksek araç gürültüsü gibi ölçüm verilerinin doğruluğunu etkileyebilecek durumların meydana gelmesi durumunda ölçümler tekrarlanmıştır (Morgül ve Dal, 2012). Gürültü ölçümlerinde cihaz yerden yaklaşık olarak $1.2 \mathrm{~m}$ yukarıda konumlandırılarak ölçümler tamamlanmıştır (Şekil 3). 


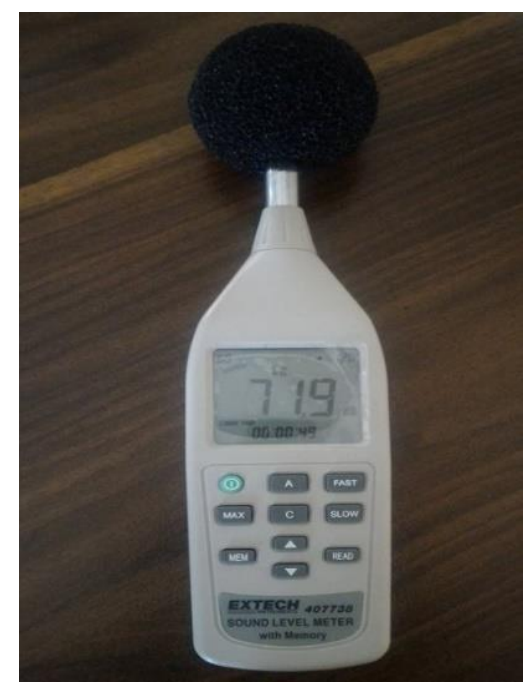

Şekil 2. Ölçüm materyali

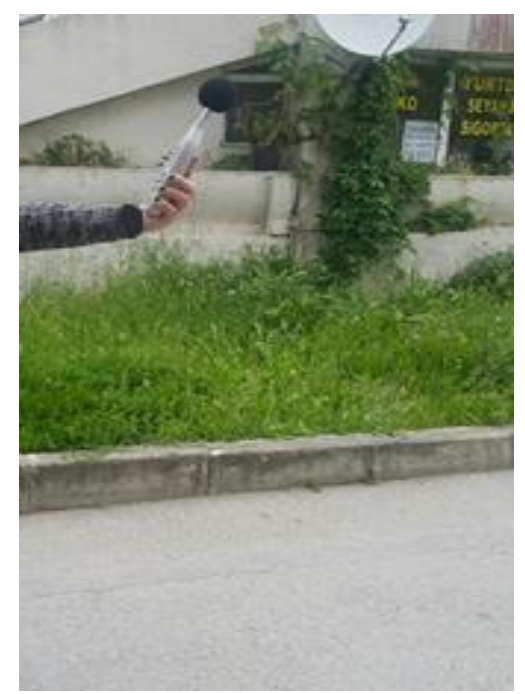

Şekil 3. Ölçümlerin alınış şekli

Çalışmada elde edilen veriler SPSS 23 (IBM, 2019) yazılımı ile istatistiksel olarak değerlendirilmiştir. İstatistiksel değerlendirmede ölçüm noktaları ve ölçüm zamanları arasındaki farklılıklar tek yönlü varyans analizi ile test edilmiştir. İstatistiksel açıdan önemli olan farklılıklar için Games-Howell analizi ile çoklu karşılaştırma yapılmıştır. Eşit olmayan varyanslar ve eşit olmayan örnek boyutları için tasarlanmış olan bu analiz yöntemi, q istatistik dağılımını temel almaktadır. GamesHowell test istatisiği, hem "student t", hem de genişletilmiş t modülü tabanında çalıştı̆̆ından bu test istatistiği "liberal çoklu karşılaştırma testi" olarak adlandırılmaktadır (Games, 1971). Ayrıca, ölçüm noktaları ve ölçüm zamanlarının elde edilen gürültü değerleri üzerindeki etkisi çok yönlü varyans analizi ile test edilmiştir.

\section{Bulgular ve tartışma}

Kent içi gürültü seviyeleri özellikle insan yoğunluğunun yüksek olduğu yerler açısından önemlidir. Bu yerler insanların toplu olarak, eğitim ve tedavi ihtiyaçlarını karşıladığı ve gürültüden etkilenmenin yüksek düzeylerde olduğu kurumlar ile insanların fiziksel ve psikolojik olarak kendisini tekrar kazanabilmesini sağlayan dinlenme, eğlenme, gezi, serbest zamanlarını değerlendirme gibi çeşitli aktiviteleri kapsayan geniş eylem alanlarıdır.

Çalışma kapsamında, Dikkaldırım Mahallesi'nde bulunan Dikkaldırım ve Bent Caddeleri üzerinde toplamda 6 nokta belirlenerek ölçümler yapılmıştır. Noktalar belirlenirken taşıt trafiğine yakınlık, cadde giriş çıkışları ve kavşaklar dikkate alınmıştır.

Birinci nokta Dikkaldırım Caddesi'nin Çekirge Devlet Hastanesi ve Askeriye arasinda kalan bölgeden seçilen noktadır. Bu noktanın aynı zamanda taşıt trafiğinin yoğun olduğu Değirmen Sokak ile de bağlantısı vardır. Yapılan ölçümler neticesinde sabah en yüksek değer $97 \mathrm{dBA}$, öğle 85 $\mathrm{dBA}$, akşam ise $94 \mathrm{dBA}$ olarak elde edilmiştir (Şekil 4). Çevresel Gürültünün Değerlendirilmesi ve Yönetimi Yönetmeliği'nde (ÇGDYY) mevcut olan yollarda gürültüye hassas kullanımlardan eğitim, kültür ve sağlık alanlarının ağırlıklı olduğu yerler için belirlenen sınır değerler, gündüz vakitleri için $65 \mathrm{dBA}$, akşam vakitleri için $60 \mathrm{dBA}$ ve gece vakitleri için $55 \mathrm{dBA}$ 'dır (Anonim, 2010). Oluşan gürültü değerlerinin büyük çoğunluğunun ÇGDYY'de belirtilen sinır değerlerin üzerinde seyrettiği görülmektedir. Hastaneye yakınlığ 1 ve yoğun taşıt trafiğinin bulunduğu Değirmen Sokak ile bağlantısının olması nedeniyle, bu noktada yüksek gürültü değerlerinin oluştuğu düşünülmektedir. Aynı zamanda cadde girişinin dar olması sebebiyle de araç trafiğinin oluştuğu gözlenmiştir. 


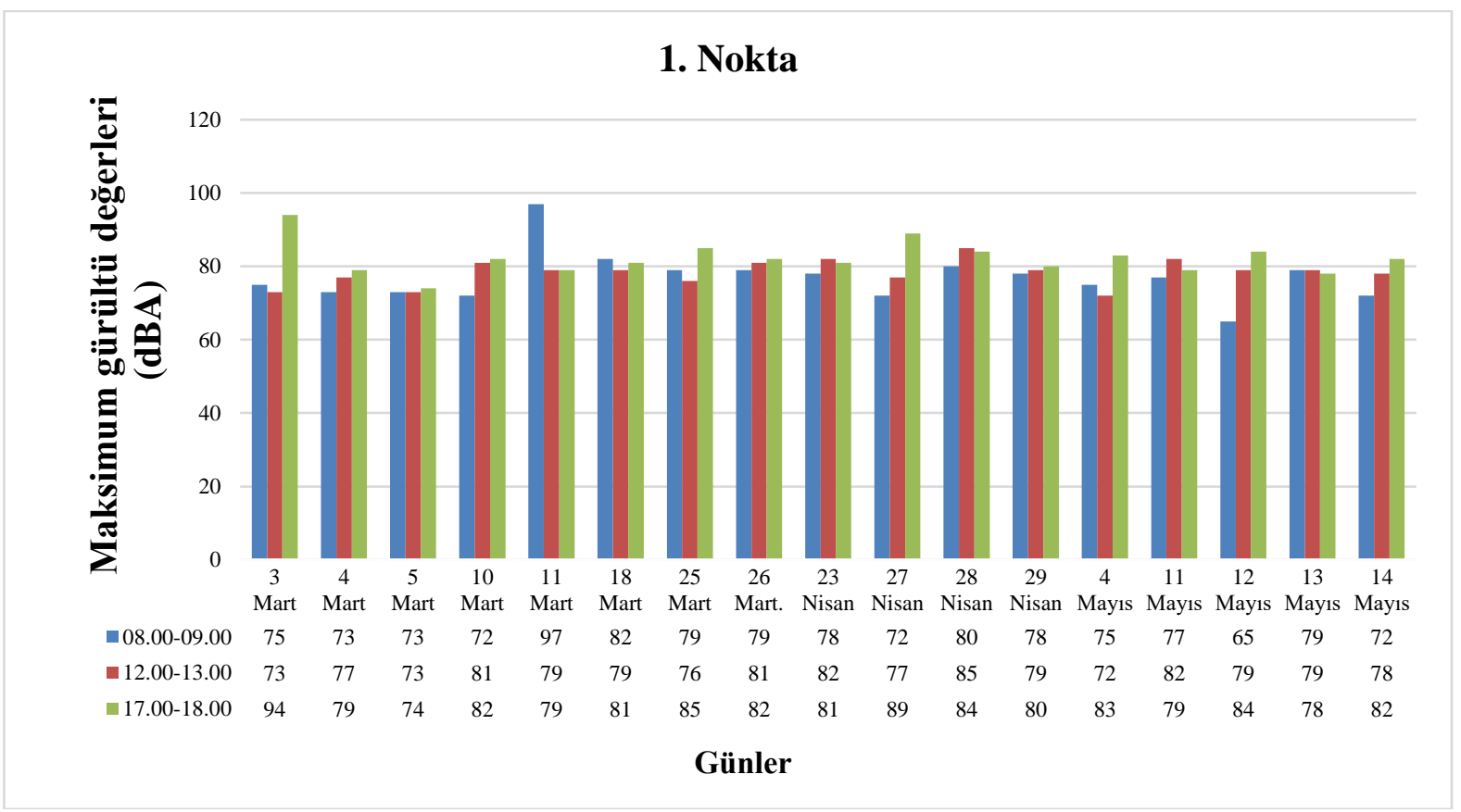

Şekil 4. Birinci noktada elde edilen maksimum gürültü değerleri

İkinci nokta Dikkaldırım Caddesi üzerinde işyerlerinin yoğunlukta olduğu bölgede yer almaktadır. İkinci noktada alınan ölçümlerde, minimum $65 \mathrm{dBA}$, maksimum $91 \mathrm{dBA}$ değerleri okunmuştur (Şekil 5). Sabah en yüksek değer 78 dBA, öğle $87 \mathrm{dBA}$, akşam ise $91 \mathrm{dBA}$ 'dır. ÇGDYY'de ticari yapılar ile gürültüye hassas kullanımların birlikte bulunduğu alanlardan işyerlerinin yoğun olarak bulunduğu alanlar için belirlenen sınır değerler göz önüne alındığında, gündüz vakitleri için belirlenen sinır değer olan 70 dBA'nın gündüz ölçümlerin çoğunda aşıldığı, akşam vakitleri için belirlenen sınır değer olan 65 dBA'nın ise akşam ölçümlerinin tamamında aşıldığı gözlenmiştir. $\mathrm{Bu}$ noktada iş yeri yoğunluğunun yanı sıra taşı yoğunluğunun da fazla olduğu belirlenmiştir.

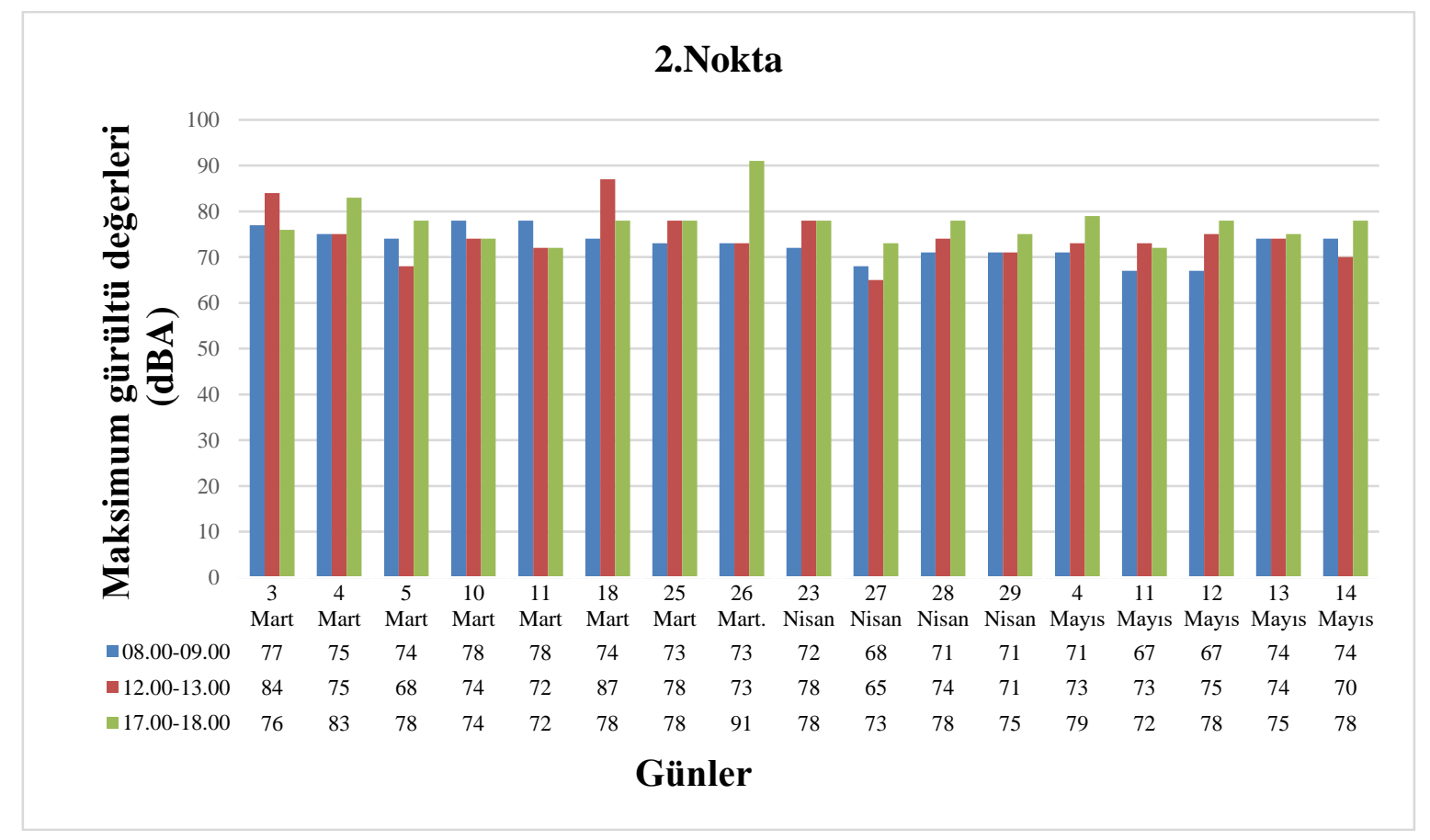

Şekil 5. İkinci noktada elde edilen maksimum gürültü değerleri 
Üçüncü nokta Dikkaldırım Caddesi üzerinde bulunan bir otobüs durağıdır. Bu noktanın bulunduğu alanda yoğun olarak işyerleri yer almaktadır. Bu nedenle insan yoğunluğu ve taşıt yoğunluğu oldukça fazladır. Bu noktada yapılan ölçümler sonucunda, minimum $77 \mathrm{dBA}$, maksimum 89 dBA değerleri elde edilmiştir (Şekil 6). Sabah ve öğle vakitlerinde oluşan en yüksek değer $87 \mathrm{dBA}$, akşam vakitlerinde ise $89 \mathrm{dBA}$ 'dır. ÇGDYY'de ticari yapılar ile gürültüye hassas kullanımların birlikte bulunduğu alanlardan işyerlerinin yoğun olarak bulunduğu alanlar için belirlenen sınır değerler göz önüne alındığında, gündüz ve akşam vakitleri için belirlenen sınır değerlerin ölçümlerin tamamında aşıldığ gözlenmiştir.

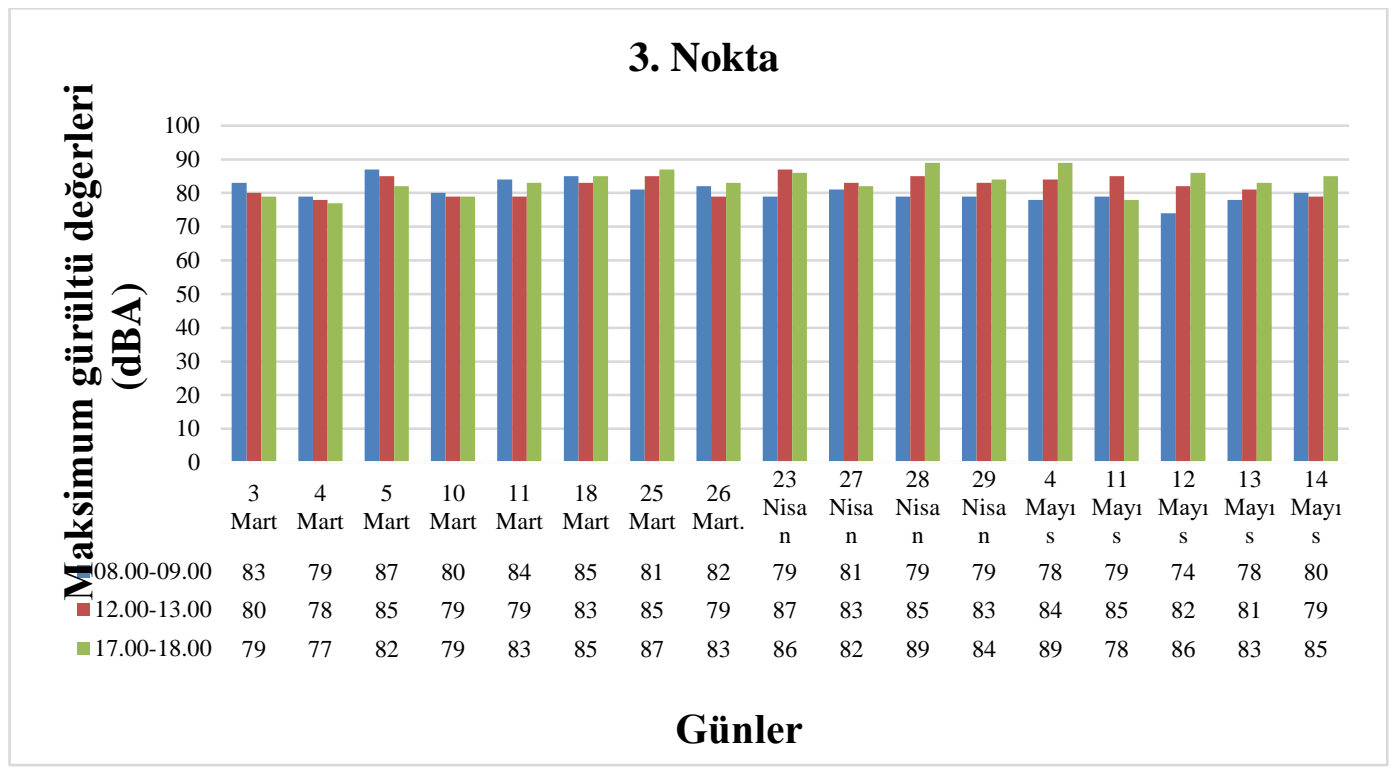

Şekil 6. Üçüncü noktada elde edilen maksimum gürültü değerleri

Dördüncü nokta Mihraplı Camii'nin önünde, Dikkaldırım Caddesi ile Bent Caddesi'ni bağlayan kavşak üzerinde seçilmiştir. $\mathrm{Bu}$ noktada taşıt trafiğinin yoğunluğu göze çarpmaktadır. Ölçümler sonucunda minimum $65 \mathrm{dBA}$, maksimum $93 \mathrm{dBA}$ değerleri okunmuştur. Vakitlere göre oluşan en yüksek değerler sabah $84 \mathrm{dBA}$, öğle $87 \mathrm{dBA}$, akşam ise $93 \mathrm{dBA}$ olarak belirlenmiştir (Şekil 7). ÇGDYY'de mevcut yollarda gürültüye hassas kullanımlardan eğitim ve kültür alanlarının bulunduğu bölgeler için verilen sınır değerler olan gündüz $65 \mathrm{dBA}$ ve gece $60 \mathrm{dBA}$ olan sinır değerlerin gündüz ölçümlerinin çoğunda, gece ölçümlerinin ise tamamında aşıldığı belirlenmiştir.

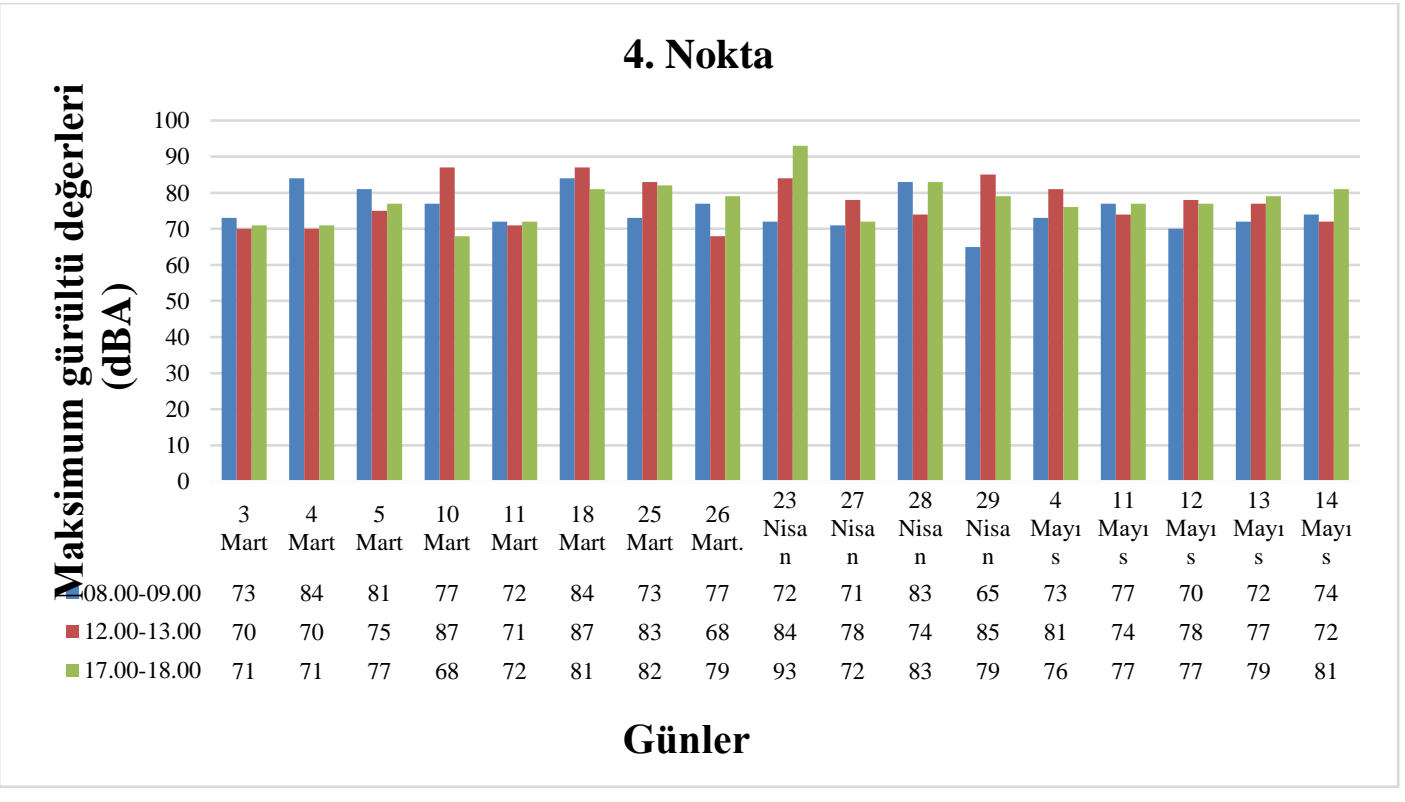

Şekil 7. Dördüncü noktada elde edilen maksimum gürültü değerleri 
Beşinci nokta Hayran Caddesi üzerinde Sadi Etkeser İlkokulu'nun önünde seçilmiştir. Okulun karşısında tomruk yükleme alanı bulunmakta olup, zaman zaman yük kamyonları giriş çıkış yapmaktadır. Beşinci noktada yapilan ölçümlerde minimum $63 \mathrm{dBA}$, maksimum $83 \mathrm{dBA}$ değerleri okunmuştur (Şekil 8). Vakitlere göre oluşan en yüksek değerler sırasıyla sabah $83 \mathrm{dBA}$, öğle 83 $\mathrm{dBA}$, akşam ise $82 \mathrm{dBA}$ şeklindedir. ÇGDYY'de mevcut yollarda gürültüye hassas kullanımlardan eğitim ve kültür alanlarının bulunduğu bölgeler için belirlenen gündüz $65 \mathrm{dBA}$ ve gece $60 \mathrm{dBA}$ olan sınır değerlerin gündüz ölçümlerinin çoğunda, gece ölçümlerinin ise tamamında aş1ldı̆̆ belirlenmiştir. Beşinci noktanın bulunduğu Hayran Caddesi Dikkaldırım Mahallesi'nin en yoğun caddelerinden biridir. Acemler-Dikkaldırım Acemler-Nilüfer arasında bağlantı yolu olduğu için taşıt yoğunluğu oldukça fazladır. Bu yüzden mart ayındaki değerler oldukça yükssek çıkmıştır. Ancak Hayran Caddesi'nin Dikkaldırım Caddesi ile bağlandığı kısımda içme suyu isale hattı çalışmasından dolayı yol trafiğe kapatılmış, bu yüzden nisan ve mayıs aylarında ölçüm değerlerinde düşüşler gözlenmiştir.

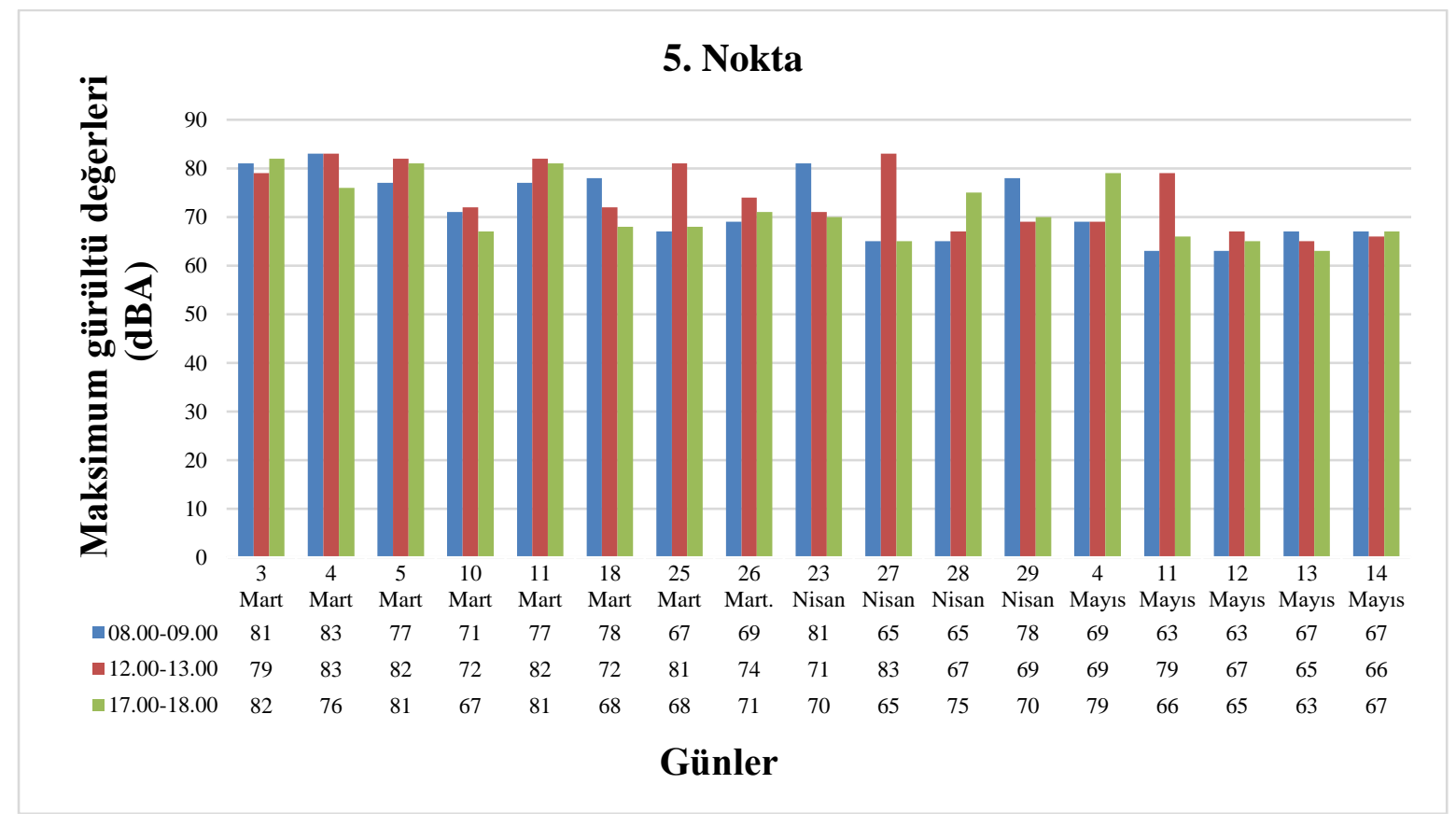

Şekil 8. Beşinci noktada elde edilen maksimum gürültü değerleri

Altıncı nokta Timsah Arena Stadyumu'nun önünde yer almakta olup, Hayran Caddesi üzerinde bulunmaktadır. $\mathrm{Bu}$ noktada gerçekleştirilen ölçümlerde, minimum $64 \mathrm{dBA}$, maksimum $85 \mathrm{dBA}$ değerleri okunmuştur (Şekil 9). Sabah en yüksek değer $81 \mathrm{dBA}$, öğle $85 \mathrm{dBA}$, akşam ise $83 \mathrm{dBA}$ olarak ölçülmüştür. ÇGDYY'de mevcut yollarda gürültüye hassas kullanımlardan eğitim ve kültür alanlarının bulunduğu bölgeler için verilen sınır değerler olan gündüz $65 \mathrm{dBA}$ ve gece $60 \mathrm{dBA}$ olan değerlerin gündüz ölçümlerinin çoğunda, gece ölçümlerinin ise tamamında sağlanamadığ belirlenmiştir. Caddenin trafiğe kapatılması sebebiyle ölçüm değerlerinde belirli zamanlarda düşüş gözlenmiş̧tir. Stadyumun önü olması sebebiyle ölçümlerin yüksek olması beklenmiştir, ancak ölçüm tarihleri ile maç tarihleri denk gelmediğinden bu noktadaki ana gürültü kaynağını karayolu trafiği oluşturmaktadır. 


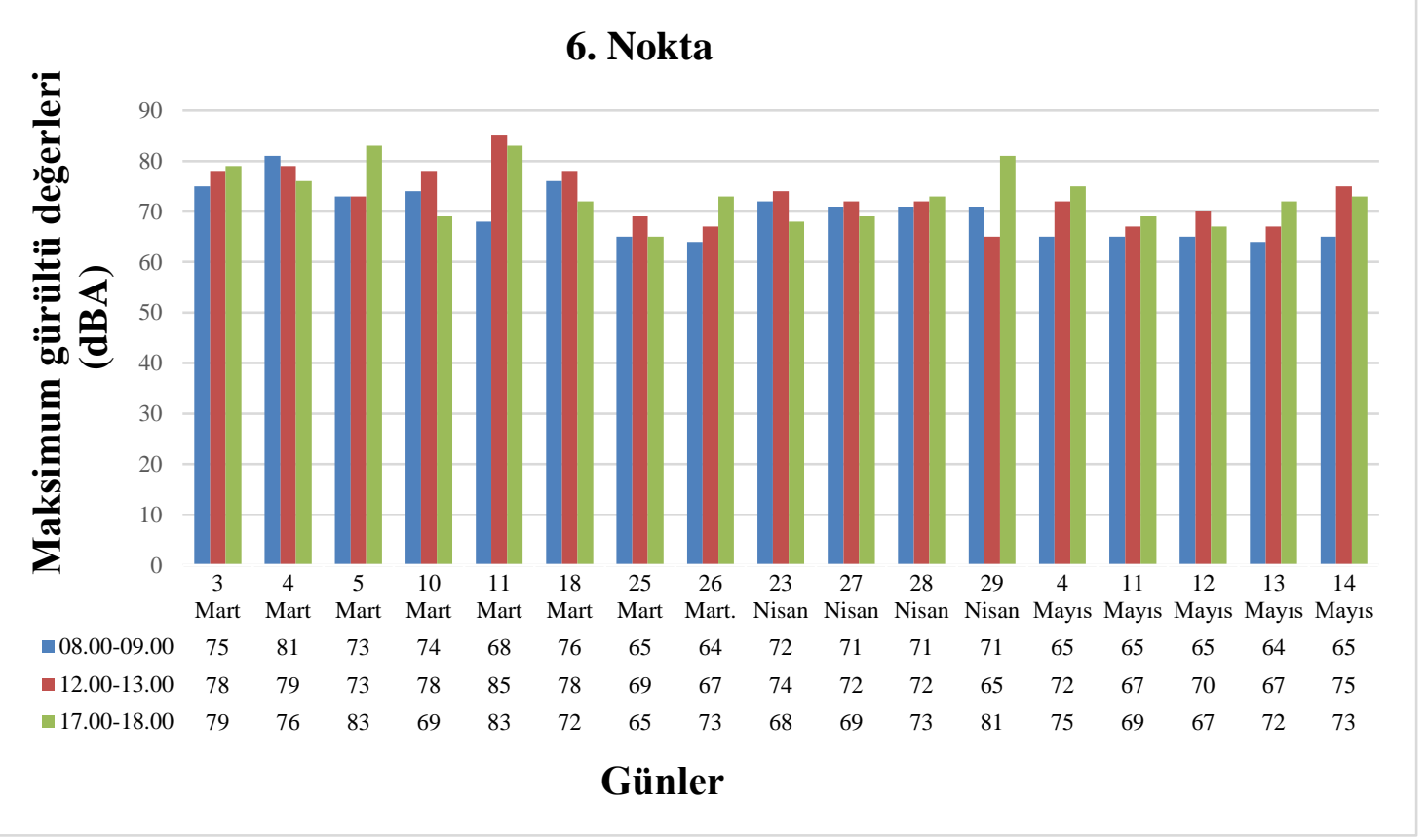

Şekil 9. Altıncı noktada elde edilen maksimum gürültü değerleri

Tablo 1'de hafta içi ve hafta sonu oluşan maksimum gürültü düzeyleri arasındaki değişim yer almaktadır.

Tablo 1. Hafta içi ve hafta sonu oluşan maksimum gürültü düzeyleri arasındaki değişim

\begin{tabular}{lcccccc}
\hline & \multicolumn{2}{c}{ Sabah } & \multicolumn{2}{c}{ Öğle } & \multicolumn{2}{c}{ Akşam } \\
\cline { 2 - 7 } Ölçüm noktaları & $\begin{array}{c}\text { Hafta içi } \\
\text { (dBA) }\end{array}$ & $\begin{array}{c}\text { Hafta } \\
\text { Sonu } \\
\text { (dBA) }\end{array}$ & $\begin{array}{c}\text { Hafta içi } \\
\text { (dBA) }\end{array}$ & $\begin{array}{c}\text { Hafta sonu } \\
\text { (dBA) }\end{array}$ & $\begin{array}{c}\text { Hafta içi } \\
\text { (dBA) }\end{array}$ & $\begin{array}{c}\text { Hafta sonu } \\
\text { (dBA) }\end{array}$ \\
\hline 1. nokta & 73.71 & 79.67 & 80.3 & 78.3 & 85 & 80.1 \\
\hline 2. nokta & 71.3 & 73.8 & 74 & 74.6 & 75.71 & 78.6 \\
\hline 3. nokta & 79.14 & 81.4 & 82.57 & 81.9 & 83.14 & 83.5 \\
\hline 4. nokta & 74.86 & 75.4 & 77.43 & 77.2 & 74.86 & 79.4 \\
\hline 5. nokta & 68.14 & 74.4 & 73.71 & 74.5 & 71.3 & 71.5 \\
\hline 6. nokta & 69.43 & 69.9 & 72.71 & 73.2 & 71.57 & 74.6 \\
\hline
\end{tabular}

Tablo 1 incelendiğinde, seçilen noktaların trafiğin yoğun olduğu caddelerin üzerinde bulunmasından dolayı hafta içi ve hafta sonu ölçüm sonuçlarının yüksek değerlerde oluştuğu düşünülmektedir. Bilgen (2017) Nevşehir kent merkezinde ticari faaliyetlerin ve trafiğin yoğun olduğu bölgede gerçekleştirdiği gürültü belirleme ve haritalandırma çalışmalarında gürültü ölçümü gerçekleştirilen noktalarda ana gürültü kaynağının trafik gürültüsü olduğunu belirlemiştir. Çamlı ve Şahinkaya, (2018) gelişmiş sanayiye sahip ve yoğun nüfusa sahip bölgelerde ulaşımın taşıdığı yüksek önem nedeniyle bu bölgelerde trafiğin en önemli gürültü kaynakları arasında yer aldığı belirtilmektedir.

Dikkaldırım Mahallesi'nde belirlenen 6 noktanın sabah ölçümlerinin toplam 17 adedinin 10'unda maksimum değer üçüncü noktada okunmuștur. Ölçümler arasında oluşan en yüksek değer ise birinci noktada 11 Mart günü $97 \mathrm{dBA}$ olarak ölçülmüsştür (Şekil 10). Bu değeri $87 \mathrm{dBA}$ ile üçüncü nokta takip etmiştir. Bu noktalarda, taşıt kaynaklı olarak değerler artış göstermiştir. Sabah ölçüm vakitleri işe gidiş saatlerine denk geldiği için bu noktalarda bulunan caddeler üzerinde önemli trafik yoğunluğu gözlenmiştir. 


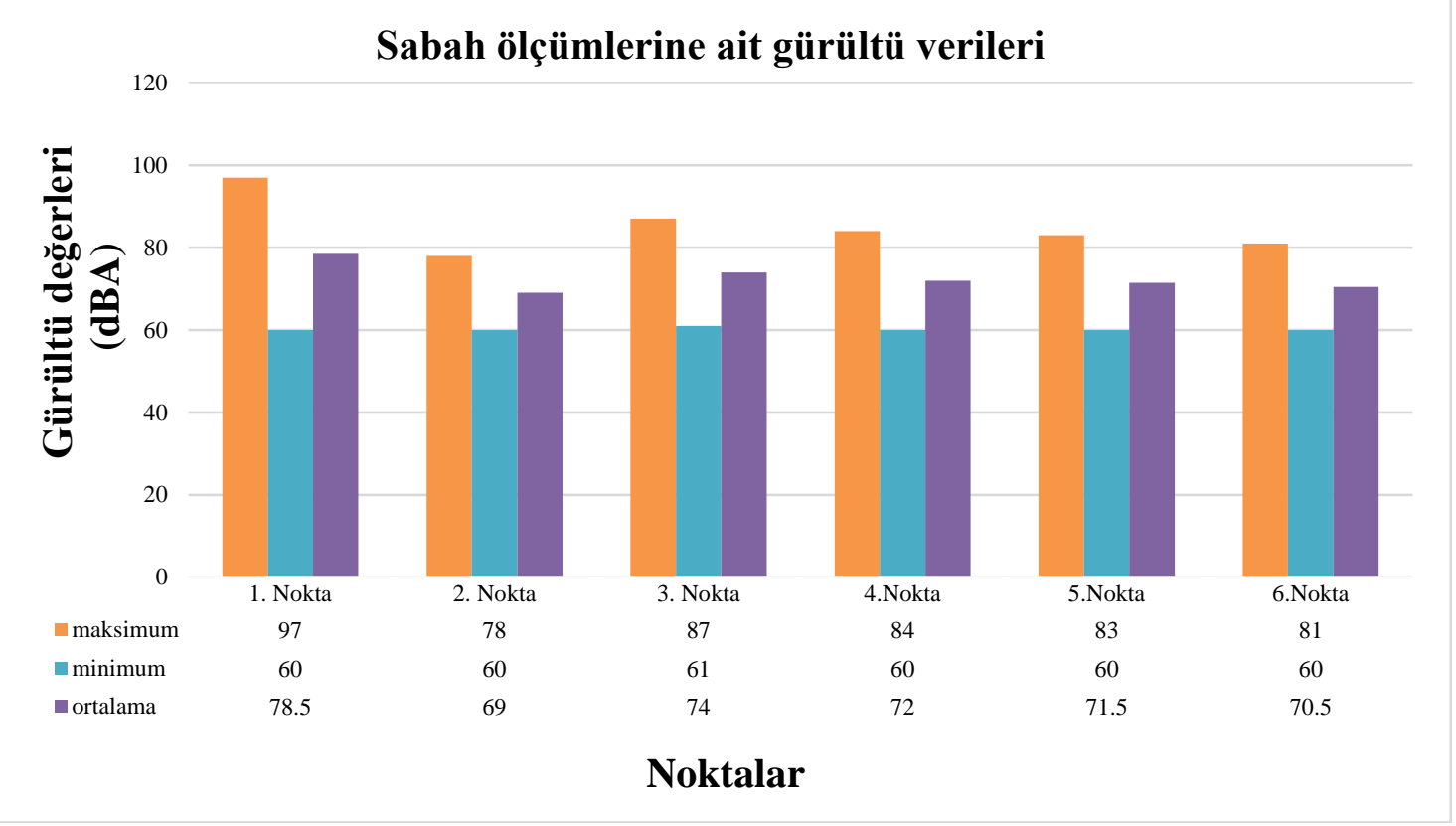

Şekil 10. Sabah ölçümlerine ait gürültü verileri

Noktaların öğle ölçümlerine ait en yüksek değer 2., 3. ve 4. noktalarda 87 dBA olarak ölçülmüştür (Şekil 11). $\mathrm{Bu}$ noktalarda, taşıt ve yaya trafiğinin fazla olması dolayısıyla diğer noktalara göre daha yüksek gürültü değerlerinin oluştuğu düşünülmektedir.

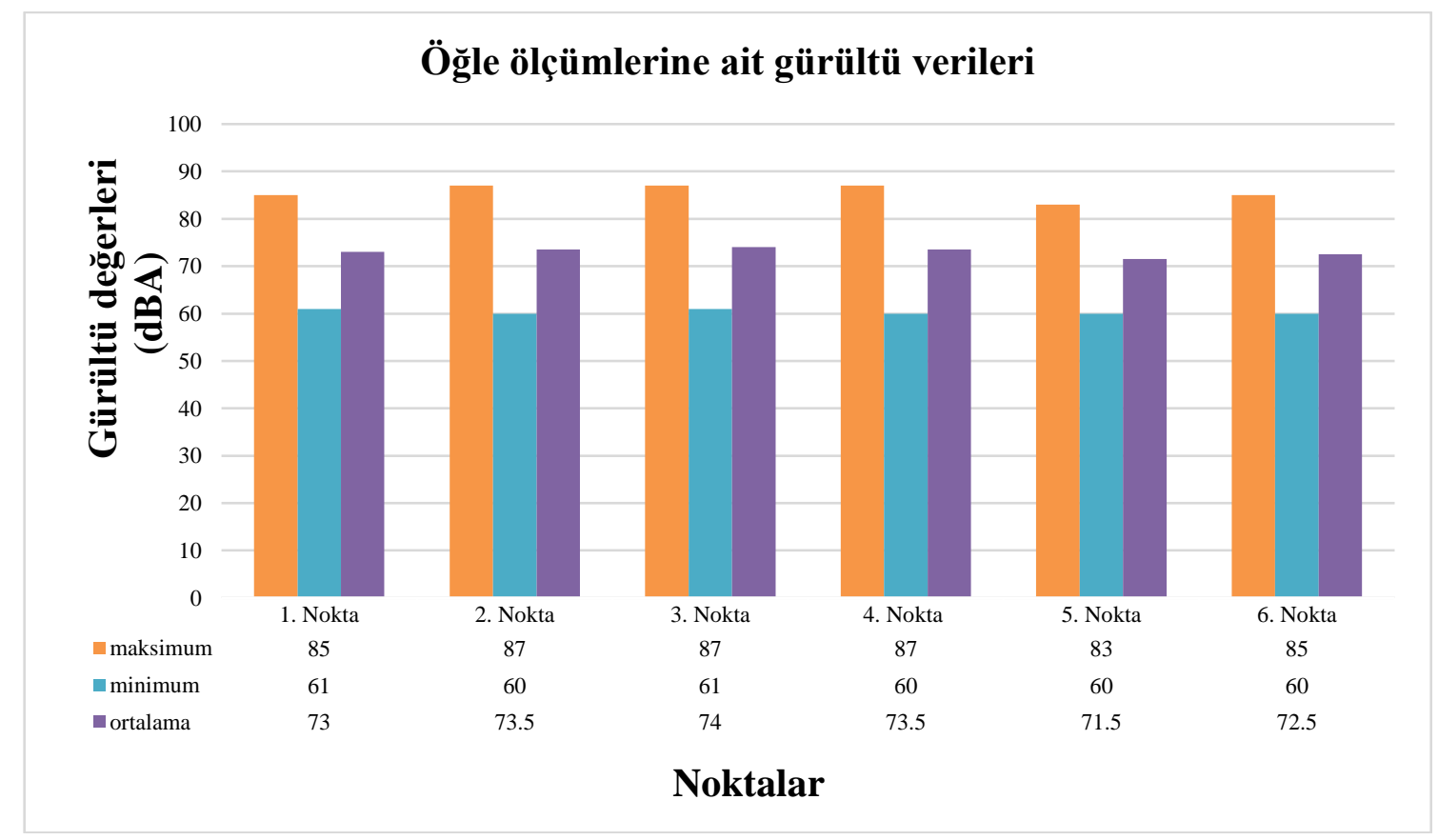

Şekil 11. Öğle ölçümlerine ait gürültü verileri

Ölçümler boyunca akşam saatinde en yüksek değer 1. noktada 3 Mart tarihinde 94 dBA olarak okunmuştur (Şekil 12). Bu noktada da benzer olarak, taşıt ve insan trafiğinin yoğun olduğu gözlenmiştir. 


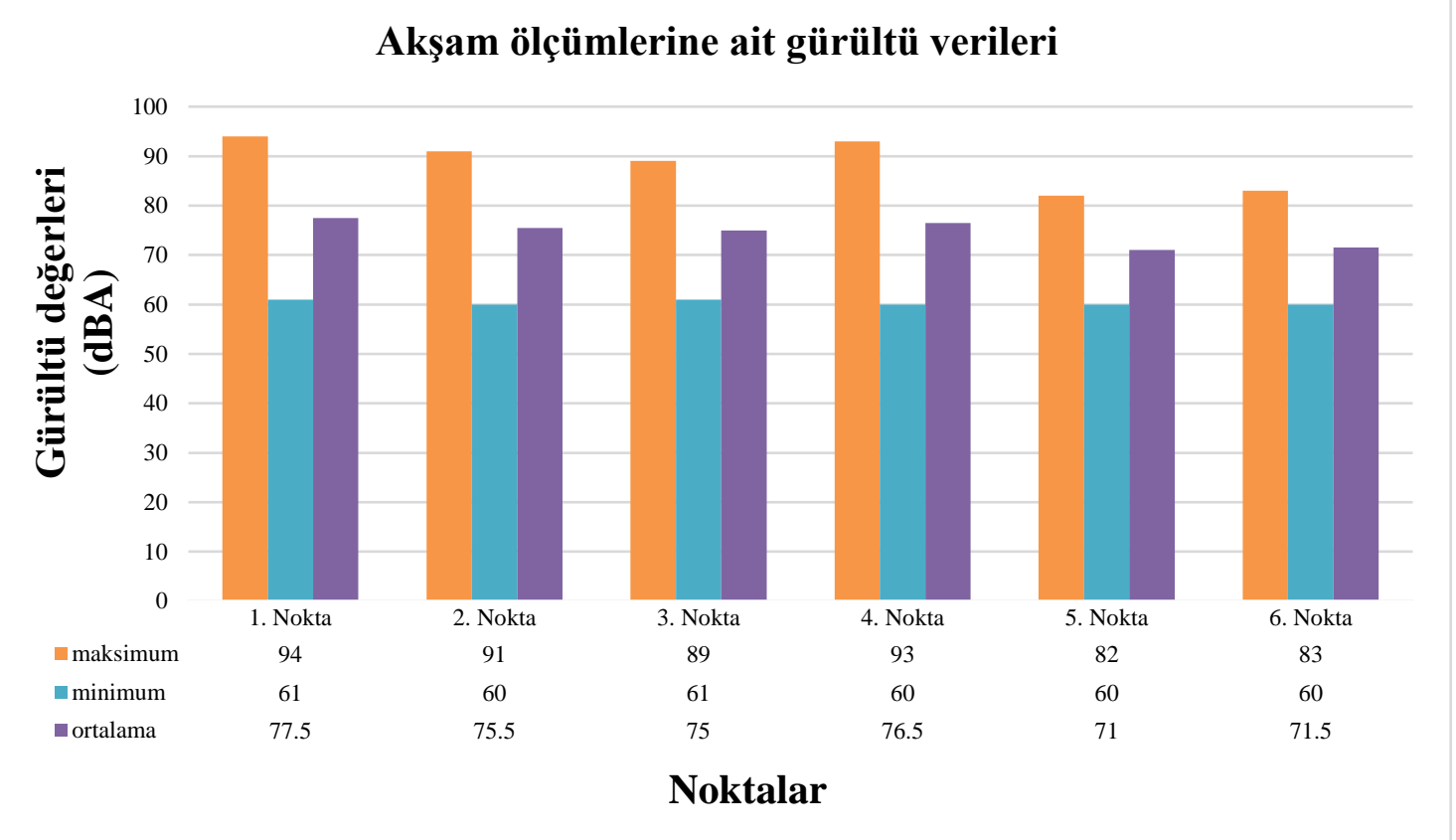

Şekil 12. Akşam ölçümlerine ait gürültü verileri

Gürültü ölçümlerinin gerçekleştirildiği 6 farkl1 nokta için yapılan tek yönlü varyans analizi sonucunda, ölçülen gürültü değerlerinin noktalar arasında istatistiksel olarak önemli derecede farklı olduğu belirlenmiştir $(\mathrm{P}<0.05)$. Farklılıkların önemli olması nedeniyle uygulanan GamesHowell analizi sonucunda ise, ölçüm noktası 1 ve
2 arasında ve ölçüm noktası 3 ve 6 arasındaki farklı1ıkların önemli olmadıkları belirlenmiştir. Tek yönlü varyans analizi sonucunda ortaya çıkan farklılıkların önemlilikleri diğer noktalar arasındaki farklılıkların önemli olmasından kaynaklanmaktadır. Varyans analizi sonuçları Tablo 2'de verilmiştir.

Tablo 2. Ölçüm yapılan noktalara göre elde edilen gürültü değerlerinin tanımlayıcı istatistikleri

\begin{tabular}{|c|c|c|c|c|c|c|c|c|}
\hline \multirow{2}{*}{$\begin{array}{r}\text { Ölçüm } \\
\text { Noktası }\end{array}$} & \multirow{2}{*}{$\mathbf{N}$} & \multirow{2}{*}{$\begin{array}{l}\text { Ortalama* } \\
\text { (dBA) }\end{array}$} & \multirow{2}{*}{$\begin{array}{l}\text { Standart } \\
\text { Sapma }\end{array}$} & \multirow{2}{*}{$\begin{array}{l}\text { Standart } \\
\text { Hata }\end{array}$} & \multicolumn{2}{|c|}{$\begin{array}{l}\text { \%95 Güven Aralığında } \\
\text { Sinırlar }\end{array}$} & \multirow[b]{2}{*}{$\begin{array}{l}\text { Minimum } \\
(\text { dBA })\end{array}$} & \multirow[b]{2}{*}{$\begin{array}{l}\text { Maksimum } \\
(\text { dBA })\end{array}$} \\
\hline & & & & & $\begin{array}{c}\text { Alt Sinır } \\
(\text { dBA })\end{array}$ & $\begin{array}{l}\text { Üst Sinır } \\
\text { (dBA) }\end{array}$ & & \\
\hline 1 & 51 & 75.00 & 3.25 & 0.46 & 74.09 & 75.91 & 68.50 & 84.00 \\
\hline 2 & 51 & 75.54 & 3.67 & 0.51 & 74.51 & 76.57 & 67.50 & 85.50 \\
\hline 3 & 51 & 66.13 & 4.11 & 0.57 & 64.97 & 67.28 & 61.00 & 79.00 \\
\hline 4 & 51 & 72.38 & 3.47 & 0.49 & 71.41 & 73.36 & 65.00 & 80.00 \\
\hline 5 & 51 & 69.04 & 4.05 & 0.57 & 67.90 & 70.18 & 61.00 & 78.50 \\
\hline 6 & 51 & 64.54 & 3.17 & 0.44 & 63.65 & 65.43 & 61.00 & 78.50 \\
\hline Toplam & 306 & 70.44 & 5.54 & 0.32 & 69.81 & 71.06 & 61.00 & 85.50 \\
\hline
\end{tabular}

$* \mathrm{P}<0.05$, Farklı harfler ile gösterilen ortalamalar arasındaki farklılıklar istatistiksel olarak önemlidir.

Çalı̧̧mada uygulanan tek yönlü varyans analizi sonucunda üç farklı ölçüm zamanında elde edilen gürültü değerleri arasındaki farkl1lıklar istatistiksel açıdan önemli bulunmamıştır. Böylece ölçüm yapılan zamanın gürültü değerleri üzerinde önemli bir etkisinin olmadığı belirtilebilir (Tablo 3).
Ölçüm noktaları ve ölçüm zamanının gürültü değerleri üzerindeki birliktelik etkisinin belirlenmesi için yapılan çok yönlü varyans analizi sonuçlarına göre, bu iki faktörün iterasyonu gürültü değerleri üzerinde istatistiksel açıdan önemli bir etkiye sahip değildir (Tablo 4). 
Tablo 3. Ölçüm zamanına göre elde edilen gürültü değerlerine ait tanımlayıcı istatistikler

\begin{tabular}{|c|c|c|c|c|c|c|c|c|}
\hline \multirow{2}{*}{ Zaman } & \multirow{2}{*}{$\mathbf{N}$} & \multirow{2}{*}{$\begin{array}{l}\text { Ortalama* } \\
\text { (dBA) }\end{array}$} & \multirow[b]{2}{*}{$\begin{array}{l}\text { Standart } \\
\text { Sapma }\end{array}$} & \multirow[b]{2}{*}{$\begin{array}{l}\text { Standart } \\
\text { Hata }\end{array}$} & \multicolumn{2}{|c|}{$\begin{array}{c}\text { \%95 Güven } \\
\text { Aralığında Sinırlar }\end{array}$} & \multirow{2}{*}{$\begin{array}{l}\text { Minimum } \\
\text { (dBA) }\end{array}$} & \multirow{2}{*}{$\begin{array}{l}\text { Maksimum } \\
\quad(\text { dBA })\end{array}$} \\
\hline & & & & & $\begin{array}{l}\text { Alt } \\
\text { Sinir (dBA) }\end{array}$ & $\begin{array}{c}\text { Üst Sinır } \\
\text { (dBA) }\end{array}$ & & \\
\hline \multirow{2}{*}{$\begin{array}{l}\text { Sabah } \\
\text { Öğle }\end{array}$} & 102 & 70.15 & 5.12 & 0.51 & 69.14 & 71.15 & 61.00 & 81.50 \\
\hline & 102 & 70.92 & 6.11 & 0.61 & 69.72 & 72.12 & 61.00 & 85.50 \\
\hline Akşam & 102 & 70.25 & 5.37 & 0.53 & 69.19 & 71.30 & 61.00 & 83.00 \\
\hline Toplam & 306 & 70.44 & 5.54 & 0.32 & 69.81 & 71.06 & 61.00 & 85.50 \\
\hline
\end{tabular}

*P $>0.05$, ortalamalar arasındaki farkl1l1klar istatistiksel olarak önemsizdir.

Tablo 4. Ölçüm zamanı ve noktaları iterasyonuna göre elde edilen gürültü değerlerine ait tanımlayıcı istatistikler

\begin{tabular}{cccccc}
\hline \multirow{2}{*}{ Zaman } & Ölçüm & & & \multicolumn{2}{c}{ \%95 Güven Aralı̆̆ında Sinırlar } \\
& Noktası & Ortalama & Standart Hata & Alt Sınır & Üst Sınır \\
\hline \multirow{3}{*}{1} & & & 72.631 & 76.134 \\
& 2 & 74.382 & .890 & 72.895 & 76.399 \\
& 3 & 74.647 & .890 & 64.395 & 67.899 \\
& 4 & 66.147 & .890 & 70.689 & 74.193 \\
& 5 & 72.441 & .890 & 67.513 & 71.016 \\
& 6 & 69.265 & .890 & 62.248 & 65.752 \\
\hline & 1 & 64.000 & .890 & 73.337 & 76.840 \\
& 2 & 75.088 & .890 & 75.072 & 78.575 \\
& 3 & 76.824 & .890 & 64.631 & 68.134 \\
& 4 & 66.382 & .890 & 71.189 & 74.693 \\
& 5 & 72.941 & .890 & 67.072 & 70.575 \\
& 6 & 68.824 & .890 & 63.689 & 67.193 \\
\hline & 65.441 & .890 & 73.778 & 77.281 \\
& 1 & 75.529 & .890 & 73.395 & 76.899 \\
& 2 & 75.147 & .890 & 64.101 & 67.605 \\
& 3 & 65.853 & .890 & 70.013 & 73.516 \\
& 4 & 71.765 & .890 & 67.278 & 70.781 \\
& 5 & 69.029 & .890 & 62.425 & 65.928 \\
\hline
\end{tabular}

Bu çalışmaya benzer olarak Çerçevik vd., (2018), Bilecik ili kent merkezinde gerçekleştirdikleri çalışmada şehrin ana karayolunda meydana gelen gürültü kirliliği belirlenmeye çalışılmış olup, ölçüm gerçekleştirilen noktalarda oluşan gürültünün yönetmelikle belirlenen $63 \mathrm{dBA}$ sınır değerinin 10-15 dBA üzerinde seyrettiği gözlenmiştir. Delikanlı vd., (2014), Bartın kent merkezinde trafik kaynaklı oluşan çevresel gürültünün belirlenmesi amaciyla gerçekleştirilen çalışmada, araç yoğunluğunun bulunduğu yedi noktada ölçümler yapılarak sabah ve akşam vakitlerinde oluşan gürültü düzeyleri tespit edilmiştir. Şehir merkezinde ölçüm yapılan noktalarda oluşan gürültü düzeylerinin tüm vakitlerinde ÇGDYY'de belirlenen sınır değerleri aştığ 1 gözlenmiştir. Kentte trafik kaynaklı gürültü sorununun ciddi boyutlara ulaştığı ve gürültü azaltıcı önlemlerin alınması gerektiği belirlenmiştir. Giresun'da 99 noktada yapılan gürültü ölçümleri ve coğrafi bilgi sistemi ile haritalama çalışmasında; limanın şehir içinde, kafe ve düğün salonlarının konut bölgelerinde bulunmasından dolayı kentteki sanayi, eğlence ve trafik gürültüsünün birbirine karıştığı ve yoğunluğu artırdığı görülmüştür. Üç caddede 68 
dBA değeri aşılmıştır (Kalıpcı ve Dursun, 2009). Yine, Nevşehir il merkezinde 60 istasyonda yapılan trafik kaynaklı gürültü ölçümleri ve coğrafi bilgi sistemi ile yapılan haritalama çalışmasında ise ana arterlerde ölçümlerden elde edilen sonuçların insan sağlığı açısından zararlı olduğu ve tespit edilen önlemlerin bir an önce uygulamaya geçirilmesinin kent merkezinde yaşayan insanların sağlığının korunmasında son derece yarar sağlayacağı bildirilmiştir (Kalıpcı vd., 2020).

\section{Sonuç}

$\mathrm{Bu}$ çalışmada, Bursa ilinin Osmangazi ilçesine bağlı Dikkaldırım Mahallesi'nde oluşan gürültü seviyesinin belirlenmesi amacıyla gürültü ölçümleri yapılarak, bölgedeki gürültü kaynakları belirlenmeye çalışılmış ve oluşan gürültü düzeyleri ÇGDYY'de verilen sınır değerlerle karşılaştırılıp yorumlanmıştır. Oluşan gürültü değerlerinin ÇGDYY'de belirlenmiş olan gürültü sınır değerlerinin çoğunlukla üzerinde seyrettiği gözlenmiştir. Trafik gürültüsünün ölçüm noktaları çevresinde büyük bir tehlike potansiyeli oluşturduğu görülmüss, bölgede yaşayan halkın sağlık ve refahının korunması amacıyla trafik kaynaklı gürültünün azaltılması gerektiği ortaya çıkmıştır.

Trafik gürültüsünün azaltılması amacıyla;

- İncelenen bölgenin gürültü haritasının oluşturularak maruz kalınan gürültü seviyelerinin belirlenmesi,

- İmar planlarında gürültü haritalarının da göz önünde bulundurularak yapım çalışmalarının yürütülmesi,

- Yeşil dalga uygulamasıyla yoğun trafiğin yaşandığı noktalarda bekleme süresinin azalımının sağlanması,

- Araç bakımlarının zamanında yapılması,

- Karayolları kenarında gürültü oluşumunu engellemek amaciyla yapay yahut bitkisel materyal kullanılması,

- İlgili kamu kuruluşları, üniversitelerin ilgili bölümleri ve Sivil Toplum Kuruluşları tarafından şehir genelinde gürültü kirliliği seviyesinin azaltılması için gürültü eylem planlarının hazırlanarak bir an önce hayata geçirilmesi gerekmektedir.

\section{Kaynaklar}

Aktürk, N., Akdemir, O. ve Üzkurt, İ. (2003). Trafik 1şık sürelerinin neden olduğu çevresel taşıt gürültüsü. Gazi Üniversitesi Mühendislik Mimarlık Fakültesi Dergisi, 18(1), 71-87.

Anonim. (2010). Çevresel Gürültünün Değerlendirilmesi ve Yönetimi Yönetmeliği, T.C. Resmi Gazete (27601, 4 Haziran 2010).

Anonim. (2021). Extech 407738 Sound Level Meter with Memory. https://www.instrumart.com/products/24271/ext ech-407738-sound-level-meter-with-memory (Erişim Tarihi: 30.03 .2021 )

Bilgen, İ. (2017). Nevşehir il merkezinde trafik kaynaklı gürültü düzeyleri ölçümü ve gürültü haritasının hazırlanması. Yüksek Lisans Tezi, Nevşehir Hacı Bektaş Veli Üniversitesi Fen Bilimleri Enstitüsü, Nevşehir.

Çamlı, H.İ. ve Şahinkaya, S. (2018). Doğal bir taş olan pomza ile gürültü izolasyon malzemesi üretimi. Yüksek Lisans Tezi, Nevşehir Hacı Bektaş Veli Üniversitesi, Fen Bilimleri Enstitüsü, Nevşehir.

Çerçevik, A.E., Kandemir, S.Y., Yıldız, M. ve Çelik, M. (2018). Bilecik ili şehir içi yollardan kaynaklı gürültü kirliliğinin ölçülmesi ve değerlendirilmesi. Afyon Kocatepe University Journal of Science and Engineering, 18(1), 366374. https://doi.org/10.5578/fmbd.66688

Dadaş, E. ve Demirel, F. (2019). İş yerinde maruz kalınan gürültünün ulusal ve uluslararası mevzuatlar bağlamında incelenmesi. 4. Uluslararası İş Güvenliği ve Çalışan Sağlığ Kongresi, (ss. 330-341). Ankara.

Delikanlı, N.E., Yücedağ, C. ve Kapdı, A. (2014). Bartın kentinde araç trafiğinden kaynaklı gürültü kirliliği üzerine bir ön çalışma. Bartın Üniversitesi Mühendislik ve Teknoloji Bilimleri Dergisi, 2, 21-40.

Games, P.A. (1971). Multiple comparisons of means. American Educational Research Journal, 8, 531564.

IBM. (2019). SPSS 23 Statistics software, USA.

İlgün, A., Çöğürcü, M.T., Özdemir, C., Kalıpcı, E. and Şahinkaya, S. (2010). Determination of sound transfer coefficient of boron added waste cellulosic and paper mixture panels. Scientific Research and Essays, 5(12),1530-1535.

Kalıpcı E. and Arslan F. (2007). Determination of noise pollution knowledge in the sport centers of Konya city. Journal of International Environmental Application \& Science, 2(3\&4), 63-69. 
Kalıpcı E. and Dursun Ş. (2009). Presentation of Giresun city traffic noise pollution map via geographical information system. Journal of Applied Sciences, 9(3), 479-487.

Kalıpç1, E. 2017. Avanos ilçe merkezinde trafik kaynaklı gürültü kirliliğinin mekansal analizi. Nevşehir Bilim ve Teknoloji Dergisi, 6(1), 2029. https://doi.org/10.17100/nevbiltek.309489

Kalıpc1, E., Bilgen, İ. and Cüce, H. (2020). Nevsehir City Center Spatial Analysis of Noise Pollution by Using Geographical Information System. Karadeniz Fen Bilimleri Dergisi, 10(2), 253-265. https://doi.org/10.31466/kfbd.777168

Kaplanoğlu, R. (2021, Şubat 14). Dikkaldırım Mahallesi. https://www.bursa.com/wiki/Dikkaldirim_Maha llesi

Morgül, Ö.K. ve Dal, H. (2012). Sakarya ili şehir merkezinin gürültü kirliliği üzerine bir ön çalışma. SAÜ. Fen Bilimleri Dergisi, 16(2), 8391.

Morova, N., Şener, E., Terzi, S., Beyhan, M. ve Harman, B.I. (2010). Süleyman Demirel Üniversitesi yerleşkesinin gürültü haritalarının coğrafi bilgi sistemleri ile hazırlanması. Süleyman Demirel Üniversitesi Fen Bilimleri Enstitüsü Dergisi, 14(3), 271-278.

Öden, M.K. ve Bilgin İ. (2019). Sarayönü ilçe merkezinde trafik kaynaklı gürültü kirliliğinin araştırılması. Çukurova Üniversitesi Mühendislik-Mimarlık Fakültesi Dergisi, 34(1), 103-114

Özdemir, C., Savur, A., Kalıpcı, E., Sahinkaya, S. and Demirci, M.T. (2011). Determination and control of noise pollution risk points at the level of touristic hotels. Middle-East Journal of Scientific Research, 7(1), 95-102.

Özdemir, C., Kalıpcı E., Öden M.K., Özdöner A. ve Şahinkaya S. (2012). Konya il merkezinde trafik kaynaklı gürültü kirliliği ölçümü ve insan sağlığına etkileri. 21.Ulusal Biyoloji Kongresi (ss.851-852). İzmir.
Özyonar, F. ve Peker, İ. (2008). Sivas kent merkezindeki çevresel gürültü kirliliğinin araştırılması. Ekoloji, 18(69), 75-80.

Paşaoğlu, A. (2013). Eyüp Hasdal-Kemerburgaz yolu Göktürk Mevkiinde otoyoldan kaynaklanan çevresel gürültünün değerlendirilmesi, Gürültü Haritasının Hazırlanması ve Gürültü Perdesi Modeli. Yüksek Lisans Tezi, Bahçeşehir Üniversitesi Fen Bilimleri Enstitüsü, İstanbul.

Savaş, S. (2019). İstanbul Kavacık Mevkiinde TEM Otoyolundan kaynaklanan gürültünün haritalanması ve gürültü perdesi modelinin uygulanması. Yüksek Lisans Tezi, Tekirdağ Namık Kemal Üniversitesi Fen Bilimleri Enstitüsü, Tekirdağ.

Taşkaya, S. ve Sesli, F.A. (2019). Gürültü kirliliğinde stratejik ile lokal konumsal verilerin Power Testi ile analizi, Elazığ İli İzzetpaşa Örneği. Uluslararası Doğu Anadolu Fen Mühendislik ve Tasarım Dergisi (IJEASED), 1(1), 1-13.

T.C. Çevre ve Orman Bakanlığı. (2011). Çevresel Gürültü Ölçüm ve Değerlendirme Kilavuzu. Çevre Yönetimi Genel Müdürlüğü, Ankara.

Tekin, V. (2020). Canlı performansların ses şiddeti ve duyma bozuklukları bağlamında incelenmesi. Yüksek Lisans Tezi, İnönü Üniversitesi Sosyal Bilimler Enstitüsü, Malatya.

Tercan, Ş.H. ve Yaman, G. (2021). Kent içi trafikten kaynaklanan stratejik gürültü haritalarının değerlendirilmesi. Doğal Afetler ve Çevre Dergisi, 7(1), 27-40. https://doi.org/10.21324/dacd.786159

Torun, F.E. ve Bingül, Z. (2014). Demiryollarından kaynaklanan çevresel gürültü ve Erzurum ili örneği. Iğdır Üniversitesi Fen Bilimleri Enstitüsü Dergisi, 4(4), 67-74.

WHO. (2011). Burden of Disease from Environmental Noise: Quantification of healthy life years lost in Europe. World Health Organization. Regional Office for Europe. https://apps.who.int/iris/handle/10665/326424 